EISSN: 2706-7955 ISSN: 2077-4605

DOI: $10.36632 /$ mejar $/ 2021.10 .2 .32$

Journal homepage: www.curresweb.com

Pages: 472-482

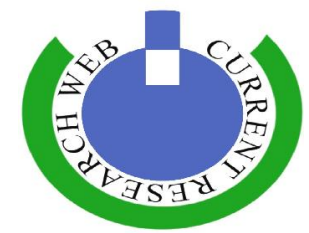

\title{
Effect of Sowing Dates on Growth, Development and Pod Production of Snap Been (Phaseouls Vulgaris L.) Varieties during Summer Season
}

\author{
Magda A. F. Shalaby and Sohair K. Ibrahim
}

Department of Botany, National Research Centre, Dokki, P.O. Box 12622, Cairo, Egypt

Received: 07 February $2021 \quad$ Accepted: 05 April $2021 \quad$ Published: 20 April 2021

\begin{abstract}
Two field experiments were carried out in the experimental farm of the faculty of Agriculture, Moshtohor, Benha University during two successive summer season; to study the effect of sowing dates March $1^{\text {st }}$ referred as early sowing date, April $1^{\text {st }}$ as medium sowing date and May $1^{\text {st }}$ as late sowing date. Four cultivars were tested in the experiment namely Paulista, Samantha, Narina and Bronco. The data for vegetative growth and chemical composition was taken at 50 days from sowing. Flower behavior as well as quantity and quality of green pods were determined. 1- All vegetative aspects i.e plant length, number of leaves and branches per plant as well as fresh weight of shoot were significantly increased with early sowing on the $1^{\text {st }}$ of March. Cv. Bronco reflected the highest value of these vegetative criteria. On the other hand, the dry matter percentage of the shoots was increased with delaying seed sowing from March $1^{\text {st }}$ to May $1^{\text {st }} .2$ - Early sowing $\left(1^{\text {st }}\right.$ March $)$ led to significant increases in all assayed photosynthetic pigments (chl. (a), (b) and carotenoids) as well as mineral constituent (N, P, K). Cv. Paulisa followed by cv. Bronco reflected the highest values. Early sowing ( $1^{\text {st }}$ march) exhibited the maximum increase in reducing, non-reducing and total sugars as well as nucleic acids (RNA\& DNA). Cv. Paulista reflected the highest level for all these parameters. 3- Flowering behavior showed that early sowing date $\left(1^{\text {st }}\right.$ March) exhibited the highest values of both number of flowers, pods per plant and fruit set percentage. Plants of cv. Bronco Possessed the superiorly in this respect followed by cv. Paulista. 4 - Sowing snap bean seed in early planting $\left(1^{\text {st }}\right.$ March $)$ significantly increased green pod yield per plant as well as feddan followed by cv. Bronco, cv. Paulista then cv. Narina. Meanwhile $\mathrm{cv}$. Samantha produced the lowest yield. Worth to be mentioning that cv. Paulista improved pod quality in all measured physical and chemical parameters of pods. It can be concluded that cv. Bronco can be recommended on the early sowing date $\left(1^{\text {st }}\right.$ March $)$ to obtain high green pod yield. However, for better quality of pods $\mathrm{cv}$. Paulista at early sowing $\left(1^{\text {st }}\right.$ March $)$ could be recommended.
\end{abstract}

Keywords: Phaseouls vulgaris L. Photosynthetic pigments, Growth, Yield, Sowing dates.

\section{Introduction}

Snap bean Phoseouls vulgaris $\mathrm{L}$ is one of the most important legume vegetable not just for export or national consumption levels but also for the food security level regarding to its high nutritious value. Snap bean cultivated under open field, low tunnel and greenhouse conditions while the production of snap bean under greenhouse presented the main export yield. Egypt is a large-scale producer and exporter of green beans and is ranked the world's seventh largest exporter of green beans with a market share $8 \%$ (HEIA, 2003).

The cultural practices and sowing date influence yield, yield characteristics and quality parameters of green bean.Therefore, selection of the most suitable variety, determining suitable sowing date and applying appropriate cultural practices are very important for increasing quality and yield of green bean. Among the various factors, optimum sowing date and best variety are of primary importance to obtain potential yield (Amanullah et al., 2002).

Corresponding Author: Magda A. F. Shalaby, Department of Botany, National Research Centre, Dokki, P.O. Box 12622, Cairo, Egypt. 
Snap bean varieties are currently classified as those with fleshy pods and those with slender pods. Pod quality attributes are the most important factors, which affect the percentage of exportable yield. Many investigators reported that the vegetative growth, total and exportable yield as well as pod quality of snap bean (Phaseolus vulgaris L.) are greatly affected by genotype of the variety (Abou ElHassan et al., 1993; Mohamed, 1997; Amer et al., 2002 ; Dhanjal et al., 2001).

This crop is widely used as protein source with highly nutritive value in human nutrition in the world (El-Noemani et al., 2010)

Increasing crop production can be achieved through the proper agriculture practice as using high yielding ability cultivars and selecting the suitable plant date. Therefore, this field experiment was conducted to study growth, development, chemical constituents, quantity and quality of yield for four cultivars sown at three sowing dates to find out the suitable variety and optimum date of planting to raise its potential as a profitable horticultural crop.

\section{Material and Method}

The experimental plant used was snap bean Phaseouls vulgaris L. and four cultivars named Paulista, Samantha, Narina and Bronco. The plants were sown for two successive seasons at three sowing dates $1^{\text {st }}$ March, $1^{\text {st }}$ April and $1^{\text {st }}$ May, referred as early, medium and late sowing dates, respectively. The maximum and minimum temperatures are represented in Table (1).

Table 1: Maximum and minimum temperature $\left({ }^{\circ} \mathrm{C}\right)$ during the two seasons of study.

\begin{tabular}{lcccc}
\hline & Seasons & \multicolumn{2}{c}{$\mathbf{1}^{\text {st }}$ season } & \multicolumn{2}{c}{$\mathbf{2}^{\text {nd }}$ season } \\
\cline { 2 - 5 } Month & Max & Min & Max & Min \\
\hline March & 21.40 & 13.17 & 22.31 & 13.51 \\
April & 26.63 & 14.21 & 27.32 & 14.60 \\
May & 32.56 & 17.15 & 33.72 & 18.10 \\
June & 33.62 & 21.72 & 34.10 & 22.12 \\
July & 34.80 & 22.71 & 35.64 & 23.18 \\
\hline
\end{tabular}

A split plot design with four replicates was adopted. The sowing date treatments were distributed on main plots whereas the cultivar treatments were randomly arranged in the sub-plots. Each experimental plot included four ridges of $3.5 \mathrm{~m}$ length and $60 \mathrm{~cm}$ width with an area of $8.4 \mathrm{~m}^{2}$. Mineral fertilization with ammonium sulphate at $200 \mathrm{~kg}$, superphosphate at $300 \mathrm{~kg}$ and potassium sulphate at $150 \mathrm{~kg}$ per fed. were used and the amount of fertilizers were divided into three equal doses added after complete germination, at flowering and at fruit setting.

Samples were collected at 50 days from sowing. Tewelve plants from each experiment plot were taken for vegetative growth characters and chemical analysis. Photosynthetic pigments (chlorophyll (a), chlorophyll (b) and carotenoid) were determined in fresh leaves by the method recommended by Metzner et al., (1965).

Nucleic acid RNA and DNA were estimated in fresh shoots by the method of Siprin (1958), total nitrogen was determined according to the conventional micro-kieldahl method Pirie (1955). Reducing, non-reducing and total sugars content as described by Dubios et al., (1965). Phsophorus content was estimated according to the method of Chapman and Pratt (1978). Potassium was determined by using flame photometer according to Brown and Lilleland (1946).

\subsection{Yield of green pods}

At harvest 60 to 56 days after sowing, green pods in each experimental plot was picked, weight and pod yield per plant as well as pod yield per feddan was recorded.

For pod quality, a random sample of 50 pod for each plot was taken and the physical properties were recorded including pod length, pod diameter and pod weight. In addition total carbohydrate percentage was determined as described by Dubios et al., (1965) Protein content as well as fiber percentage evaluated according to the method of A.O.A.C (1990).

All data were subjected to statistical analysis according to the method of Gomez and Gomez (1989). 


\section{Results and Discussion}

\subsection{Vegetative growth}

Data represented in Table (2) show the effect of sowing date, cultivar and their interaction on vegetative growth characteristics of bean plants during the two seasons of study.

The results revealed that the early sowing on $1^{\text {st }}$ of March showed the highest significant values for plant length, number of branches and leaves as well as fresh weight during the two seasons. These results lend more support to the finding of other investigators who found increase of in vegetative growth of Phoseouls vulgaris L. at the early sowing dates of such legume (El-Sefi et al., 1991; Ismail et al., 1996; Karas et al., 1999 and Amer et al., 2002a).

Table 2: Effect of sowing date and cultivar as well as their interaction on vegetative growth characters of bean plants during the two experimental seasons.

\begin{tabular}{|c|c|c|c|c|c|c|c|c|c|c|c|}
\hline \multirow{2}{*}{\multicolumn{2}{|c|}{$\begin{array}{l}\text { Seasons } \\
\text { Sowing dates }\end{array}$}} & \multicolumn{5}{|c|}{$1^{\text {st }}$ season } & \multicolumn{5}{|c|}{$2^{\text {nd }}$ season } \\
\hline & & $\begin{array}{l}\text { Plant } \\
\text { length } \\
(\mathrm{cm}) \\
\end{array}$ & $\begin{array}{c}\text { No. of } \\
\text { branches/ } \\
\text { plant }\end{array}$ & $\begin{array}{c}\text { No. of } \\
\text { leaves/ } \\
\text { plant }\end{array}$ & $\begin{array}{c}\text { Fresh } \\
\text { weight/ } \\
\text { plant (g) } \\
\end{array}$ & $\begin{array}{r}\text { Dry matter } \\
\text { of plant of } \\
\text { foliage }(\%) \\
\end{array}$ & $\begin{array}{c}\text { Plant } \\
\text { length } \\
(\mathrm{cm})\end{array}$ & $\begin{array}{c}\text { No. of } \\
\text { branches/ } \\
\text { plant } \\
\end{array}$ & $\begin{array}{c}\text { No. of } \\
\text { leaves/ } \\
\text { plant }\end{array}$ & $\begin{array}{c}\text { Fresh } \\
\text { weight/ } \\
\text { plant (g) }\end{array}$ & $\begin{array}{r}\text { Dry matter } \\
\text { of plant of } \\
\text { foliage (\%) } \\
\end{array}$ \\
\hline $\operatorname{March} 1^{\text {st }}$ & & 33.9 & 5.2 & 13.9 & 55.6 & 13.6 & 32.8 & 4.6 & 12.9 & 53.3 & 13.7 \\
\hline April $1^{\text {st }}$ & & 30.2 & 4.3 & 11.6 & 41.2 & 14.9 & 28.7 & 3.6 & 11.4 & 40.5 & 15.1 \\
\hline May $1^{\text {st }}$ & & 25.6 & 2.9 & 9.7 & 34.9 & 16.8 & 24.35 & 2.7 & 8.9 & 33.4 & 17.0 \\
\hline L.S.D at 0. & 0.05 & 0.9 & 0.6 & 0.5 & 0.9 & 0.2 & 0.7 & 0.3 & 0.6 & 0.6 & 0.2 \\
\hline \multirow{4}{*}{ Cultivar } & Paulista & 29.7 & 4.9 & 12.4 & 44.9 & 14.9 & 27.6 & 3.3 & 11.5 & 43.3 & 15.0 \\
\hline & Samantha & 24.2 & 3.3 & 10.1 & 40.5 & 14.5 & 23.5 & 2.7 & 9.2 & 39.2 & 14.7 \\
\hline & Narnia & 32.6 & 4.3 & 11.4 & 42.8 & 15.7 & 31.2 & 4.2 & 10.6 & 41.9 & 15.9 \\
\hline & Bronco & 33.1 & 4.9 & 13.0 & 47.4 & 15.3 & 32.3 & 4.3 & 13.2 & 45.1 & 15.5 \\
\hline \multicolumn{2}{|c|}{ L.S.D at 0.05} & 0.8 & 0.4 & 0.6 & 1.4 & 0.2 & 0.7 & 0.3 & 0.6 & 0.9 & 0.2 \\
\hline \multirow{4}{*}{$\operatorname{March} 1^{\text {st }}$} & Paulista & 33.7 & 5.3 & 14.4 & 58.3 & 13.3 & 32.3 & 4.4 & 13.5 & 55.1 & 13.5 \\
\hline & Samantha & 27.2 & 4.3 & 11.4 & 49.5 & 13.1 & 26.2 & 3.5 & 10.4 & 47.3 & 13.2 \\
\hline & Narnia & 36.2 & 6.2 & 13.5 & 53.3 & 14.5 & 35.2 & 5.2 & 12.3 & 52.3 & 14.6 \\
\hline & Bronco & 38.3 & 6.3 & 16.3 & 61.2 & 13.5 & 37.3 & 5.4 & 15.5 & 58.5 & 13.7 \\
\hline \multirow{4}{*}{ April 1 ${ }^{\text {st }}$} & Paulista & 29.2 & 4.3 & 12.3 & 39.3 & 14.5 & 26.2 & 3.3 & 11.4 & 39.1 & 14.7 \\
\hline & Samantha & 24.2 & 3.4 & 10.6 & 40.4 & 14.2 & 24.2 & 2.4 & 9.3 & 40.2 & 14.3 \\
\hline & Narina & 33.2 & 4.3 & 11.4 & 42.0 & 15.7 & 32.2 & 4.2 & 11.3 & 41.3 & 15.8 \\
\hline & Bronco & 34.2 & 5.3 & 12.2 & 43.3 & 15.1 & 32.2 & 4.3 & 13.5 & 41.3 & 15.3 \\
\hline \multirow{4}{*}{$\begin{array}{c}\text { May } \\
\mathbf{1}^{\text {st }}\end{array}$} & Paulista & 26.2 & 3.4 & 10.5 & 37.2 & 16.8 & 24.4 & 2.3 & 9.4 & 35.7 & 16.9 \\
\hline & Samantha & 21.3 & 2.3 & 8.4 & 31.6 & 16.3 & 20.2 & 2.2 & 7.3 & 30.2 & 16.5 \\
\hline & Narina & 28.6 & 2.4 & 9.4 & 33.1 & 17.0 & 26.3 & 3.1 & 8.2 & 32.3 & 17.2 \\
\hline & Bronco & 26.7 & 3.1 & 10.6 & 37.6 & 17.2 & 27.2 & 3.3 & 10.6 & 35.5 & 17.4 \\
\hline \multicolumn{2}{|c|}{ L.S.D at 0.05} & 1.4 & 0.6 & 1.0 & 2.4 & 0.3 & 1.3 & 0.6 & 1.1 & 1.6 & 0.3 \\
\hline
\end{tabular}

Vegetative growth of snap bean cultivated on the $1^{\text {st }}$ of March may be attributed to the favorable prevailing temperature (Table 1) at the early planting date which encourage the increase of photosynthetic pigments content Table (3) and nutrients accumulation (Table 4) that in turn increased the vegetative growth of plants on the other hand, increase of dry weight percentage of plant foliage was reported at the latter sowing date ( $1^{\text {st }}$ May). This increase may be attributed to the reduction of water content of the plant due to the high temperature prevailing during their vegetative growth as maximum temperature reached 32.35 (Table 1) (Ibrahim et al., 2012)

Data of the two seasons revealed that all studied parameters of vegetative growth were significantly affected due the different genotypes (Table 2) cv. Bronco possessed the high values in all traits i.e plant length, number of leaves and branches per plant as well as the fresh weight and dry matter percentage followed by cv. Narina with regard to plant length and cv. Paulista for number of leaves, 
branches and the fresh weight of plant, meanwhile cv. Narina showed the highest dry matter percentage. On the other hand cv. Samantha exhibited the lowest values in all studied growth parameters. In this respect, other investigators mentioned that there were significant differences among the tested common bean cultivar in growth parameters for different used genotypes (Mohamed 1997 and Amer et al., 2002 b). The results in Table (2) showed significant effects on all the studied growth parameters due to the interaction between the tested sowing dates and the used genotypes. It is clear that early sowing $\left(1^{\text {st }}\right.$ of March) for cv. Bronco reflected the highest values in most measured growth aspects (plant length, number of leaves and branches as well as fresh weight of plants) compared to other treatments. The superiority of the studied growth criteria for $\mathrm{cv}$. Bronco may be due to the suitable temperature and the adaptation of $\mathrm{cv}$. Bronco for growth under the prevailing environmental condition than the other tested cultivars.

\subsection{Photosynthetic pigments}

Data recorded in Table (3) shows the effect of sowing date, cultivar and their interaction on photosynthetic pigments of leaves of snap bean (chlorophyll a, chlorophyll $b$, chlorophyll $a+b$ and carotenoids). It is obvious that the first sowing date (March $1^{\text {st }}$ ) has the highest concentration of the studied pigments. Whereas, these photosynthetic pigments were decreased in a descending order as bean seeds were sown on $1^{\text {st }}$ March, $1^{\text {st }}$ April and $1^{\text {st }}$ May, respectively. Other investigators reported, also decrease in chlorophylls of Phaseouls vulgaris L. leaves due to the prevailing high temperature (Cowling and Sage, 1998). Karas et al., (1999) studied the effect of two sowing dates (the last week of January and late sowing on the third week of February) on chlorophyll content of snap bean cultivars. They found that the highest level of chlorophylls exhibited in leaves of late sowing.

Table 3: Effect of sowing date and cultivar as well as their interaction on photosynthetic pigments (mg/100g. F.W) of the leaves during the two experimental seasons.

\begin{tabular}{|c|c|c|c|c|c|c|c|c|c|}
\hline \multirow{3}{*}{\multicolumn{2}{|c|}{ Sowing dates }} & \multirow{2}{*}{\multicolumn{4}{|c|}{$\begin{array}{c}1^{\text {st }} \text { season } \\
\text { Chlorophyll }\end{array}$}} & \multicolumn{4}{|c|}{$2^{\text {nd }}$ season } \\
\hline & & & & & & & Chl & phyll & \\
\hline & & (a) & (b) & $(a+b)$ & Carot.* & (a) & (b) & $(a+b)$ & Carot.* \\
\hline \multicolumn{2}{|l|}{$\overline{\text { March 1 } 1^{\text {st }}}$} & 193.1 & 133.3 & 326.4 & 136.4 & 172.9 & 124.4 & 297.3 & 117.2 \\
\hline \multicolumn{2}{|l|}{ April $1^{\text {st }}$} & 180.4 & 94.1 & 274.4 & 116.4 & 161.6 & 78.4 & 240.0 & 96.6 \\
\hline \multicolumn{2}{|l|}{ May $1^{\text {st }}$} & 171.7 & 71.2 & 212.8 & 81.3 & 122.9 & 59.4 & 182.4 & 65.9 \\
\hline \multicolumn{2}{|c|}{ L.S.D at 0.05} & 1.3 & 0.8 & 2.0 & 1.5 & 1.0 & 3.4 & 4.0 & 2.4 \\
\hline \multirow{4}{*}{ cultivar } & Paulista & 174.8 & 102.5 & 277.3 & 115.1 & 156.0 & 90.6 & 246.6 & 96.8 \\
\hline & Samantha & 169.7 & 96.1 & 265.8 & 111.6 & 149.5 & 83.3 & 232.7 & 90.1 \\
\hline & Narina & 170.7 & 98.6 & 269.2 & 110.4 & 151.5 & 87.1 & 238.5 & 91.8 \\
\hline & Bronco & 171.7 & 100.8 & 272.5 & 111.6 & 153.1 & 88.7 & 241.7 & 94.3 \\
\hline \multicolumn{2}{|c|}{ L.S.D at 0.05} & 1.1 & 1.8 & 2.7 & 1.7 & 0.9 & 2.6 & 2.7 & 1.5 \\
\hline \multirow{4}{*}{$\operatorname{March} 1^{\text {st }}$} & Paulista & 196.9 & 136.2 & 333.7 & 140.9 & 176.0 & 126.6 & 302.5 & 120.6 \\
\hline & Samantha & 190.8 & 129.5 & 32.3 & 133.3 & 169.7 & 121.7 & 291.4 & 114.5 \\
\hline & Narina & 191.9 & 131.7 & 323.5 & 135.3 & 172.3 & 124.0 & 296.3 & 115.6 \\
\hline & Bronco & 192.8 & 135.2 & 328.0 & 136.0 & 173.7 & 125.3 & 299.0 & 118.4 \\
\hline \multirow{4}{*}{ April 1 ${ }^{\text {st }}$} & Paulista & 183.3 & 96.7 & 279.9 & 119.8 & 165.2 & 83.3 & 248.6 & 100.6 \\
\hline & Samantha & 178.3 & 91.6 & 269.9 & 113.7 & 157.9 & 71.5 & 229.3 & 92.3 \\
\hline & Narina & 179.5 & 93.1 & 272.5 & 115.2 & 160.5 & 78.2 & 238.7 & 95.2 \\
\hline & Bronco & 180.4 & 49.9 & 275.3 & 117.1 & 162.9 & 80.6 & 243.5 & 98.4 \\
\hline \multirow{4}{*}{ May $1^{\text {st }}$} & Paulista & 144.3 & 74.0 & 218.3 & 84.4 & 126.8 & 62.0 & 188.8 & 69.3 \\
\hline & Samantha & 139.8 & 67.3 & 207.1 & 78.1 & 120.8 & 56.7 & 177.5 & 63.1 \\
\hline & Narina & 140.7 & 71.1 & 211.6 & 80.7 & 121.6 & 59.0 & 180.6 & 64.8 \\
\hline & Bronco & 141.9 & 72.4 & 214.3 & 81.8 & 122.5 & 60.1 & 182.6 & 66.2 \\
\hline \multicolumn{2}{|c|}{ L.S.D at 0.05} & 2.0 & 3.1 & 4.7 & 3.0 & 1.6 & 4.5 & 4.6 & 2.6 \\
\hline
\end{tabular}

The high level of photosynthetic pigments content of early sowing date in the present work may be attributed to the suitable temperature prevailing during growth of snap bean. On the contrary, plants sown on the late sowing date $\left(1^{\text {st }}\right.$ of May) showed the lowest values of photosynthetic pigment (chlorophyll a, b and carotenoids). Worth to be mention, that the temperature prevailing during May and June ranged from $\left(32-34^{\circ} \mathrm{C}\right)$ and this level of temperature was unsuitable for this stage of plant 
growth. Moreover, the results of the present study indicated substantial decrease of carotenoids content in plants sown at $1^{\text {st }}$ of May. This would be a further support to explain their low level of carotenoids act as a protective agent from photo-oxidation (Axelsson 1981) and as important antioxidant for eliminating singlet oxygen (Fyfe et al., 1995).

With regard to cultivars, the results reveal that cv. Paulista possessed the highest values in photosynthetic pigments content i.e. chlorophyll $\mathrm{a}, \mathrm{b}$ and $(\mathrm{a}+\mathrm{b})$ as well as carotenoids, followed by $\mathrm{cv}$. Bronco and cv. Narina, meanwhile cv. Samantha exhibited the least values in all assayed photosynthetic pigments in both seasons of the study. Such differences among the tested cultivars may be due to the gentic potential for such genotype. Other researchers working on bean plants reported that there were significant differences in photosynthetic pigments content among the tested cultivars (Karas et al., 1999 and Youssef, 2000).

Data in Table (3) indicate that there is a significant effect on the photosynthetic pigments due to the interaction between the tested sowing dates and the used cultivars. It is clear that, early sowing $\left(1^{\text {st }}\right.$ of March) for cv. Paulista reflected the highest values during both seasons of study. On the other hand $\mathrm{cv}$. Samantha at late sowing on of May exhibited the lowest values in this respect.

\subsection{Mineral constituents}

The present investigation showed that $\mathrm{N}, \mathrm{P}$ and $\mathrm{K}$ content decreased significantly by delaying sowing date from $1^{\text {st }}$ March to $1^{\text {st }}$ May during the two seasons (Table 4). In this connection Ibrahim et al., (2012) found that the early sowing at $1^{\text {st }}$ March increased the content of N, P, K of cv. Paulista compared to the late sowing date of $1^{\text {st }}$ May. Such increase may be attributed to the suitable temperature during plant growth.

As to the response of snap bean cultivars, the results show clearly significant difference among the different cultivars in the total N, P and K content. Cultivar Paulisata exhibited the highest values in the estimated macro elements compared to the other tested cultivars. These results are in agreement with those reported by other investigators (Hernadez et al., 1996; and Amer et al., 2002 b).

The results also indicate significant effect due to the interaction between the tested sowing dates and the used cultivars. It is obvious that early sowing $\left(1^{\text {st }}\right.$ March $)$ for $\mathrm{cv}$. Paulista reflected the highest values of $\mathrm{N}, \mathrm{P}$ and $\mathrm{K}$ in plant shoots compared to the other treatments.

Table 4: Effect of sowing date and cultivar as well as their interaction on N, P and K content of plant foliage $(\mathrm{mg} / 100 \mathrm{~g} \mathrm{D}$.W.) during the two experimental seasons.

\begin{tabular}{|c|c|c|c|c|c|c|c|}
\hline \multirow{2}{*}{ Sowing date } & \multirow[t]{2}{*}{ Seasons } & \multicolumn{3}{|c|}{ 1 $^{\text {st }}$ season } & \multicolumn{3}{|c|}{$2^{\text {nd }}$ season } \\
\hline & & $\mathbf{N}$ & $\mathbf{P}$ & $\mathbf{K}$ & $\mathbf{N}$ & $\mathbf{P}$ & $\mathbf{K}$ \\
\hline March $1^{\text {st }}$ & & 3253 & 122 & 5192 & 2662 & 115 & 4208 \\
\hline April 1 $1^{\text {st }}$ & & 2997 & 110 & 4882 & 2512 & 89 & 4047 \\
\hline May $1^{\text {st }}$ & & 2757 & 100 & 3890 & 2212 & 81 & 3074 \\
\hline L.S.D at 0 & & 78 & 6 & 77 & 105 & 7 & 65 \\
\hline \multirow{4}{*}{ cultivar } & Paulista & 3303 & 122 & 4941 & 2709 & 101 & 4012 \\
\hline & Samantha & 2829 & 116 & 4445 & 2308 & 89 & 3666 \\
\hline & Narina & 2915 & 109 & 4611 & 2395 & 93 & 378 \\
\hline & Bronco & 2829 & 97 & 4621 & 2435 & 97 & 3648 \\
\hline \multicolumn{2}{|c|}{ L.S.D at 0.05} & 68 & 9 & 126 & 59 & 8 & 81 \\
\hline \multirow{4}{*}{$\operatorname{March} 1^{\text {st }}$} & Paulista & 3443 & 135 & 5417 & 2802 & 120 & 4404 \\
\hline & Samantha & 3063 & 102 & 5045 & 2522 & 111 & 4096 \\
\hline & Narina & 3263 & 123 & 5200 & 2642 & 114 & 4208 \\
\hline & Bronco & 3263 & 129 & 5107 & 2682 & 117 & 4124 \\
\hline \multirow{4}{*}{ April $1^{\text {st }}$} & Paulista & 3323 & 120 & 5169 & 2722 & 96 & 4264 \\
\hline & Samantha & 2862 & 99 & 4673 & 2362 & 81 & 3900 \\
\hline & Narina & 3242 & 108 & 4828 & 2462 & 87 & 4068 \\
\hline & Bronco & 2922 & 114 & 4859 & 2502 & 90 & 3956 \\
\hline \multirow{4}{*}{ May $1^{\text {st }}$} & Paulista & 3143 & 111 & 4239 & 2602 & 87 & 3368 \\
\hline & Samantha & 2562 & 90 & 3619 & 2042 & 75 & 3004 \\
\hline & Narina & 2622 & 96 & 3805 & 2082 & 78 & 3060 \\
\hline & Bronco & 2702 & 105 & 3898 & 2122 & 84 & 2864 \\
\hline \multicolumn{2}{|c|}{ L.S.D at 0.05} & 119 & 15 & 219 & 103 & 14 & 137 \\
\hline
\end{tabular}




\subsection{Carbohydrate constituents}

The present study showed that reducing sugars, non-reducing sugars and total sugars content were significantly affected by sowing date (Table 5). The early sowing date followed by medium one (March $1^{\text {st }}$ and April $1^{\text {st }}$ ) showed significant increase in reducing sugars as well as total sugars compared to the late sowing ( $1^{\text {st }}$ of May). The high level of carbohydrate at the early sowing date may be due to the favorable prevailing temperature that induced the photosynthetic pigments formation which in turn encourages sugar assimilation in plants. Similar results were reported by other investigators (El-Sayed 1990 and cowling and Sage 1998).

Different cultivars revealed significant difference in reducing, non-reducing and total sugar content during the two seasons of growth. In this respect cv. Paulista showed the highest values followed by $\mathrm{Cv}$. Narina and Bronco, meanwhile Cv. Samantha exhibited the lowest value of all carbohydrate constituents.

The interaction between the sowing date and the tested cultivars revealed that $\mathrm{Cv}$. Paulista at the early sowing date ( $1^{\text {st }}$ March) showed the highest level of the formenioned carbohydrate fractions during both seasons of growth compared to the same cultivar as well as other cultivars at later sowing dates. Whereas, $\mathrm{Cv}$. Samantha at the latest sowing date ( $1^{\text {st }}$ of May) exhibited the least values in this connection.

Table 5: Effect of sowing date and cultivar as well as their interaction on sugar percentage of plant foliage and nucleic acid of leaves ( $\square \mathrm{g} / \mathrm{g}$ ) during the two experimental seasons.

\begin{tabular}{|c|c|c|c|c|c|c|c|c|c|c|c|}
\hline \multirow[b]{2}{*}{ Sowing dates } & \multirow[t]{2}{*}{ Seasons } & \multicolumn{5}{|c|}{$1^{\text {st }}$ season } & \multicolumn{5}{|c|}{$2^{\text {nd }}$ season } \\
\hline & & RS* & Non-RS & $\begin{array}{c}\text { Total } \\
\text { Sugar }\end{array}$ & RNA & DNA & RS* & $\begin{array}{c}\text { Non- } \\
\text { RS }\end{array}$ & $\begin{array}{c}\text { Total } \\
\text { Sugar }\end{array}$ & RNA & DNA \\
\hline March 1 ${ }^{\text {st }}$ & & 0.945 & 1.180 & 2.126 & 210.2 & 202.2 & 0.887 & 1.133 & 205.1 & 197.3 & 197.3 \\
\hline April 1 ${ }^{\text {st }}$ & & 0.828 & 1.092 & 1.921 & 194.5 & 187.1 & 0.775 & 1.051 & 1.827 & 190.2 & 182.9 \\
\hline May $1^{\text {st }}$ & & 0.652 & 1.033 & 1.686 & 124.3 & 119.6 & 0.546 & 0.981 & 1.527 & 119.9 & 115.7 \\
\hline L.S.D at 0.0 & & 0.117 & 0.089 & 0.079 & 0.4 & 0.4 & 0.083 & 0.148 & 0.811 & 2.4 & 1.5 \\
\hline \multirow{4}{*}{ cultivar } & Paulista & 0.893 & 1.175 & 2.060 & 182.0 & 175.0 & 0.815 & 1.112 & 1.920 & 179.0 & 172.2 \\
\hline & Samantha & 0.736 & 1.041 & 1.770 & 168.1 & 161.7 & 0.658 & 0.994 & 1.650 & 163.6 & 157.8 \\
\hline & Narina & 0.822 & 1.112 & 1.930 & 178.8 & 172.0 & 0.759 & 1.073 & 1.830 & 175.8 & 169.1 \\
\hline & Bron & 0.783 & 1.081 & 1.860 & 176.4 & 169.7 & 0.713 & 1.042 & 1.750 & 168.5 & 162.1 \\
\hline \multicolumn{2}{|l|}{ L.S.D at 0.05} & 0.068 & 0.070 & 0.082 & 1.9 & 1.8 & 0.055 & 0.082 & 0.367 & 2.9 & 2.7 \\
\hline \multirow{4}{*}{ March $1^{\text {st }}$} & Paulista & 1.081 & 1.222 & 2.300 & 218.8 & 210.5 & 0.987 & 1.175 & 2.160 & 215.5 & 207.4 \\
\hline & Samantha & 0.869 & 1.128 & 1.990 & 195.5 & 188.1 & 0.799 & 1.081 & 1.880 & 192.3 & 184.9 \\
\hline & Narina & 0.940 & 1.198 & 2.130 & 214.4 & 206.2 & 0.916 & 1.151 & 2.060 & 211.1 & 203.0 \\
\hline & Bronco & 0.893 & 1.177 & 2.070 & 212.1 & 204.1 & 0.846 & 1.128 & 1.970 & 201.6 & 194.0 \\
\hline \multirow{4}{*}{ April 1 ${ }^{\text {st }}$} & Paulista & 0.893 & 1.175 & 2.060 & 198.3 & 190.8 & 0.846 & 1.280 & 1.970 & 195.6 & 188.1 \\
\hline & Samantha & 0.775 & 1.034 & 1.800 & 188.9 & 181.7 & 0.704 & 0.963 & 1.070 & 183.4 & 176.4 \\
\hline & Narina & 0.846 & 1.081 & 1.920 & 196.1 & 188.7 & 0.799 & 1.810 & 1.880 & 194.8 & 187.4 \\
\hline & Bronco & 0.799 & 1.081 & 1.880 & 194.5 & 187.1 & 0.752 & 1.034 & 1.780 & 186.8 & 179.6 \\
\hline \multirow{4}{*}{ May $1^{\text {st }}$} & Paulista & 0.705 & 1.128 & 1.830 & 128.7 & 123.8 & 0.611 & 1.034 & 1.640 & 126.0 & 121.2 \\
\hline & Samanth & 0.564 & 0.963 & 1.520 & 119.9 & 115.3 & 0.470 & 0.940 & 1.410 & 115.0 & 112.8 \\
\hline & Narina & 0.681 & 1.057 & 1.730 & 126.0 & 121.2 & 0.564 & 0.986 & 1.550 & 121.5 & 116.8 \\
\hline & Bronco & 0.658 & 0.987 & 1.640 & 122.6 & 118.0 & 0.540 & 0.963 & 1.500 & 117.1 & 112.6 \\
\hline S.S.D at 0.0 & & 0.118 & 0.121 & 0.142 & 3.3 & 3.2 & 0.069 & 0.142 & 0.636 & 5.0 & 4.2 \\
\hline
\end{tabular}

\subsection{Nucleic acids}

Data in Table (5) indicate that there was gradual significant decrease in nucleic content by delaying sowing date till the ( $1^{\text {st }}$ of May) compared to the other two sowing dates. The same trend was obtained during both seasons of growth. Worth to be mention, that the plants sown at the delayed day ( $1^{\text {st }}$ May) were exhibited to high level of temperature over the suitable level of their growth and development. So, plants suffered from high temperature. This result are in agreement with Khalil et al., (2009) who revealed that exposure of wheat seedlings to high temperature resulted in decreased of DNA and attributed this reduction to the statement of Papadakis and Roubelakis-Angelakis (2005) who reported that high temperature stress has a role in releasing of activated reactive oxygen species which 
accompanied with the induction of DNase activity, enhanced DNA fragmentation and methylation. In this respect, other investigators reported that salinity stress decreased DNA content (Garg 2002 on soybean and Bekheta and El-Bassiouny 2005 on wheat plant).

Regarding cultivars cv. Paulista exhibited the highest level of RNA and DNA; however cv. Samantha showed the lowest values of nucleic acids.

\subsection{Flowering behavior}

The present investigation indicated that early planting $\left(1^{\text {st }}\right.$ March $)$ increased number of flowers and pod/plant as well as fruit set percentage as compared to medium and late planting date during both seasons of growth.

The enhancing effect of early sowing on vegetative growth and different assayed chemical constituents may induce flowering and fruit set of snap bean. The obtained results are confirmed by previous reports of (Ismail et al., 1996, Karase et al., 1999 and Mamata et al., 2011) (Table 6).

The cultivars also showed significant differences in these studied parameters, cv. Branco was the superior followed in descending order by cv. Paulista, Narina and Samantha respectively. The results were previously recorded by other investigators (Youssef 2000, Feleafel et al., 2001 and Brez-Barbeito et al., 2008) on snap bean.

The interaction between the tested sowing date and cultivars showed that cv. Bronco at the first sowing date reflected the highest value of number of flowers and pods as well as fruit setting percentage.

Table 6: Effect of sowing date and cultivar as well as their interaction on plant flowering behavior, fruit set percentage and number of pods/ plant during, the two experimental seasons.

\begin{tabular}{|c|c|c|c|c|c|c|c|}
\hline \multirow{2}{*}{\multicolumn{2}{|c|}{ Sowing dates }} & \multicolumn{3}{|c|}{$1^{\text {st }}$ season } & \multicolumn{3}{|c|}{$2^{\text {nd }}$ season } \\
\hline & & $\begin{array}{c}\text { No.of } \\
\text { flowers } \\
\text { /plant }\end{array}$ & $\begin{array}{c}\text { No. of pods/ } \\
\text { plant }\end{array}$ & $\begin{array}{c}\text { Fruit set. } \\
\% \%\end{array}$ & $\begin{array}{l}\text { No.of } \\
\text { flowers } \\
\text { /plant }\end{array}$ & $\begin{array}{l}\text { No. of pods/ } \\
\text { plant }\end{array}$ & $\begin{array}{c}\text { Fruit set. } \\
\%\end{array}$ \\
\hline $\operatorname{March~} 1^{\text {st }}$ & & 19.4 & 17.2 & 88.2 & 18.1 & 15.9 & 87.4 \\
\hline April $1^{\text {st }}$ & & 15.8 & 11.5 & 75.5 & 14.4 & 10.2 & 70.4 \\
\hline May $1^{\text {st }}$ & & 13.4 & 7.9 & 58.9 & 12.1 & 6.7 & 54.7 \\
\hline L.S.D at 0.0 & & 0.17 & 0.68 & 1.88 & 0.6 & 0.6 & 1.4 \\
\hline \multirow{4}{*}{ cultivar } & Paulista & 15.8 & 12.2 & 75.4 & 14.8 & 11.1 & 72.8 \\
\hline & Samantha & 13.8 & 9.8 & 69.0 & 12.8 & 8.8 & 66.2 \\
\hline & Narina & 14.9 & 11.2 & 73.5 & 13.8 & 10.1 & 71.0 \\
\hline & Bronco & 20.2 & 15.6 & 75.9 & 18.2 & 13.6 & 73.2 \\
\hline \multicolumn{2}{|c|}{ L.S.D at 0.05} & 0.87 & 0.88 & 2.58 & 0.7 & 0.7 & 2.0 \\
\hline \multirow{4}{*}{$\operatorname{March} 1^{\text {st }}$} & Paulista & 19.1 & 17.1 & 89.5 & 18.1 & 16.1 & 88.9 \\
\hline & Samantha & 17.2 & 14.2 & 82.5 & 16.2 & 13.2 & 81.4 \\
\hline & Narina & 18.0 & 15.1 & 89.4 & 17.0 & 15.1 & 88.8 \\
\hline & Bronco & 23.3 & 21.4 & 91.6 & 21.2 & 19.2 & 90.5 \\
\hline \multirow{4}{*}{ April 1 ${ }^{\text {st }}$} & Paulista & 15.3 & 11.3 & 73.8 & 14.3 & 10.2 & 71.3 \\
\hline & Samantha & 13.2 & 9.2 & 69.6 & 12.1 & 8.1 & 66.6 \\
\hline & Narina & 14.4 & 10.3 & 71.5 & 13.2 & 9.2 & 69.6 \\
\hline & Bronco & 20.3 & 15.3 & 75.2 & 18.1 & 13.4 & 74.0 \\
\hline \multirow{4}{*}{ May $1^{\text {st }}$} & Paulista & 13.1 & 8.1 & 61.8 & 12.0 & 7.0 & 58.3 \\
\hline & Samantha & 11.1 & 6.1 & 54.9 & 10.1 & 5.1 & 50.4 \\
\hline & Narina & 12.2 & 7.3 & 59.8 & 11.3 & 6.2 & 54.8 \\
\hline & Bronco & 17.0 & 10.1 & 59.4 & 15.2 & 8.4 & 55.3 \\
\hline \multicolumn{2}{|c|}{ L.S.D at 0.05} & 1.5 & 1.5 & 4.5 & 1.3 & 1.3 & 3.4 \\
\hline
\end{tabular}

\subsection{Yield of green pods}

It is clear from the results (Table 7) that there was a continuous decrease per feddan with delaying sowing date till $1^{\text {st }}$ of May compared to $1^{\text {st }}$ April and $1^{\text {st }}$ March. Such increments during the early sowing date $\left(1^{\text {st }}\right.$ March) may be attributed to the favorable prevailing temperature that encourage the vegetative growth (Table 2a, b) that ultimately led to better flowering and fruit setting percentage (Table 6) which in turn increased the number of pods per plant and consequently yield productivity. However, the high temperature during growth and production at late sowing date $\left(1^{\text {st }}\right.$ May) (Temp $\left.33-35^{\circ} \mathrm{C}\right)$ decreased 
photosynthetic production and their translocation to the reproductive organs; this reduction leads to abscission of flowers and pods (Sabal et al., 2010, Zeyada and Hussein 2014 and Kakon et al., 2018). With regard to cultivars, cv. Bronco produced the highest yield followed by Paulista, Narina and Samantha. Such results could be explained on the basis that the two cultivars (Bronco and Paulista) produced higher number of flowers, pods and high percentage of fruit setting compared to other cultivars (Table 6). Other investigators stated that varieties differ in their response (Maniruzzaman et al., 2007 and Perez-Berbeito et al., 2008).

Early sowing ( $1^{\text {st }}$ of March) of cv. Bronco reflected the highest values in weight of pods and total yield per feddan compared to other treatments, meanwhile plants of cv. Samantha produced the least values especially when grown at late sowing time ( $1^{\text {st }}$ of May).

\subsection{Green pod quality}

Green pods, produced from sowing date on ( $1^{\text {st }}$ March) (Table 7) showed the superior effect on average pod length, diameter and weight compared to other tested sowing dates. The favourable effects of early sowing date on pod characters could be related to the positive effect of such sowing date on vegetative growth (Table 2) which in turn affects the quality of produced green pods. This result coincides with the founding of other researchers (El-Seifi et al., 1991 and Reichel 1992) on frensh bean. Snap bean cultivars differ to their response to the three sowing dates, cv. Paulista reflected the highest values with respect to average pod length, and meanwhile cv. Bronco possessed the highest values of pod diameter. On the contrary, cv. Samantha recorded the lowest value of all studied criteria.

Table 7: Effect of sowing date and cultivar as well as their interaction on pod length, diameter weight as well as yield during the two experimental seasons.

\begin{tabular}{|c|c|c|c|c|c|c|c|c|c|c|c|}
\hline \multirow{2}{*}{\multicolumn{2}{|c|}{ Sowing dates }} & \multicolumn{5}{|c|}{$1^{\text {st }}$ season } & \multicolumn{5}{|c|}{$2^{\text {nd }}$ season } \\
\hline & & $\begin{array}{c}\text { Pod } \\
\text { length } \\
(\mathrm{cm})\end{array}$ & $\begin{array}{c}\text { Pod } \\
\text { diameter } \\
(\mathrm{cm})\end{array}$ & $\begin{array}{c}\text { Pod } \\
\text { weight } \\
\text { (g) }\end{array}$ & $\begin{array}{c}\text { Weight } \\
\text { of pods } \\
\text { /plant } \\
\text { (g) }\end{array}$ & $\begin{array}{l}\text { Total } \\
\text { yield/ } \\
\text { fed. } \\
\text { (kg) }\end{array}$ & $\begin{array}{c}\text { Pod } \\
\text { length } \\
(\mathrm{cm})\end{array}$ & $\begin{array}{c}\text { Pod } \\
\text { diameter } \\
(\mathrm{cm})\end{array}$ & $\begin{array}{c}\text { Pod } \\
\text { weight } \\
\text { (g) }\end{array}$ & $\begin{array}{c}\text { Weight } \\
\text { of pods } \\
\text { /plant } \\
\text { (g) }\end{array}$ & $\begin{array}{c}\text { Total } \\
\text { yield/ } \\
\text { fed. } \\
\text { (kg) }\end{array}$ \\
\hline & 11.3 & 0.71 & 3.88 & 66.48 & 4920 & 11.75 & 0.69 & 4.02 & 63.56 & 4570 \\
\hline \multicolumn{2}{|l|}{ April $1^{\text {st }}$} & 10.0 & 0.64 & 3.48 & 39.37 & 2620 & 10.25 & 0.64 & 3.56 & 35.82 & 2320 \\
\hline \multicolumn{2}{|l|}{ May $1^{\text {st }}$} & 9.0 & 0.58 & 2.79 & 21.63 & 11.60 & 8.90 & 0.58 & 3.18 & 20.45 & 1050 \\
\hline \multicolumn{2}{|c|}{ L.S.D at 0.05} & 0.31 & 0.06 & 0.22 & 2.62 & 141.46 & 0.25 & 0.04 & 0.20 & 1.78 & 82.51 \\
\hline \multirow{4}{*}{ cultivar } & Paulista & 11.2 & 0.63 & 3.11 & 43.30 & 2933 & 10.80 & 0.63 & 3.34 & 41.32 & 2720 \\
\hline & Samantha & 10.20 & 0.55 & 3.08 & 30.79 & 1973 & 9.20 & 0.55 & 3.30 & 29.24 & 1813 \\
\hline & Narina & 10.0 & 0.68 & 3.74 & 38.25 & 2560 & 10.20 & 0.67 & 3.94 & 37.00 & 2373 \\
\hline & Bronco & 9.0 & 0.70 & 3.62 & 57.56 & 4133 & 10.00 & 0.68 & 3.77 & 52.18 & 3680 \\
\hline \multicolumn{2}{|c|}{ L.S.D at 0.05} & 0.50 & 0.06 & 0.37 & 2.76 & 139.61 & 0.40 & 0.06 & 0.35 & 1.67 & 104.01 \\
\hline \multirow{4}{*}{$\operatorname{March} 1^{\text {st }}$} & Paulista & 12.50 & 0.70 & 3.58 & 69.46 & 5120 & 12.20 & 0.70 & 3.69 & 66.63 & 4720 \\
\hline & Samantha & 10.00 & 0.60 & 3.44 & 48.21 & 3360 & 10.10 & 0.60 & 3.62 & 47.02 & 3160 \\
\hline & Narina & 11.00 & 0.75 & 4.35 & 60.93 & 4560 & 11.00 & 0.70 & 4.44 & 58.98 & 4320 \\
\hline & Bronco & 11.50 & 0.80 & 4.17 & 87.34 & 6640 & 11.00 & 0.75 & 4.32 & 81.63 & 6080 \\
\hline \multirow{4}{*}{ April $1^{\text {st }}$} & Paulista & 11.00 & 0.60 & 3.03 & 39.07 & 2480 & 11.30 & 0.60 & 3.23 & 35.81 & 2320 \\
\hline & Samantha & 9.00 & 0.55 & 3.18 & 28.53 & 1760 & 9.20 & 0.55 & 3.17 & 25.33 & 1520 \\
\hline & Narina & 10.00 & 0.70 & 3.91 & 33.25 & 2160 & 10.50 & 0.70 & 4.00 & 32.20 & 1920 \\
\hline & Bronco & 10.00 & 0.70 & 3.81 & 56.64 & 4080 & 10.00 & 0.70 & 3.86 & 49.95 & 3520 \\
\hline \multirow{4}{*}{ May $1^{\text {st }}$} & Paulista & 10.00 & 0.60 & 2.71 & 21.63 & 1200 & 9.10 & 0.60 & 3.10 & 21.52 & 1120 \\
\hline & Samantha & 8.00 & 0.50 & 2.60 & 15.62 & 800 & 8.30 & 0.50 & 3.11 & 15.37 & 760 \\
\hline & Narina & 9.00 & 0.60 & 2.97 & 20.59 & 960 & 9.20 & 0.60 & 3.39 & 19.95 & 880 \\
\hline & Bronco & 9.00 & 0.60 & 2.89 & 28.70 & 1680 & 9.00 & 0.60 & 3.15 & 24.97 & 1440 \\
\hline \multicolumn{2}{|c|}{ L.S.D at 0.05} & 0.82 & 0.11 & 0.64 & 4.78 & 241.81 & 0.70 & 0.11 & 0.61 & 2.90 & 180.14 \\
\hline
\end{tabular}

\subsection{Chemical constituents of green pods}

Table (8) showed the high level of protein and carbohydrate at early sowing date ( ${ }^{\text {st }}$ March) compared to the later sowing dates at $\left(1^{\text {st }}\right.$ April $)$ or $\left(1^{\text {st }}\right.$ May). On the other hand, fiber percentage increased by delaying sowing date at $1^{\text {st }}$ April $(10.7 \%) 1^{\text {st }}$ May $12.95 \%$ compared to the first sowing date at $1^{\text {st }}$ March $(9.1 \%)$. Decreasing of protein and carbohydrate concomitant to increase of fiber 
percentage in green pods sown at the delayed sowing date ( $1^{\text {st }}$ of May), this may be due to the higher prevailing temperature which in turn may enhance the rate of respiration comparing to photosynthesis leading to deleterious effect on protein and carbohydrate metabolism and consequently affect their contents in plant tissues (Daningsih et al., 1994).

With respect to cultivars response, cv. Paulista possessed the highest values of total protein and carbohydrate contents of green pods followed by cvs. Bronco and Narina, meanwhile cv. Samantha showed the least values in this respect. Regarding to fiber percentage cv. Samantha showed the minimum percentage of fiber content; however, cv. Bronco contains the highest percentage. Thus, the green pods of $\mathrm{cv}$. Paulista showed the superior chemical constituents hence, they contain the highest values of protein and carbohydrate accompanied with low percentage of fibers. Such differences in chemical constituents content of produced pods for the studied snap bean cultivars may be due to the differences in genotype potential (Amer et al., $2002 \mathrm{~b}$ and Abdel Hakim et al., 2012).

In conclusion, cv. Bronco on early sowing date $\left(1^{\text {st }}\right.$ March showed the highest green yield. Meanwhile, cv. Paulista sown at the same sowing date produced the best quality of pods.

Table 8: Effect of sowing date and cultivar as well as their interaction on protein (mg/100g. D.W), carbohydrate and fibers percentage of green pods during two experimental seasons.

\begin{tabular}{|c|c|c|c|c|c|c|c|}
\hline \multirow[b]{2}{*}{ Sowing dates } & \multirow[t]{2}{*}{ Seasons } & \multicolumn{3}{|c|}{$1^{\text {st }}$ season } & \multicolumn{3}{|c|}{$2^{\text {nd }}$ season } \\
\hline & & $\begin{array}{l}\text { Protein } \\
\text { mg/100 } \\
\text { k.D.W }\end{array}$ & $\begin{array}{c}\text { Carbohydrate } \\
\%\end{array}$ & $\begin{array}{c}\text { Fiber } \\
\%\end{array}$ & $\begin{array}{l}\text { Protein } \\
\text { mg/100 } \\
\text { k.D.W }\end{array}$ & $\begin{array}{c}\text { Carbohydrate } \\
\% \\
\end{array}$ & $\begin{array}{c}\text { Fiber } \\
\%\end{array}$ \\
\hline$\overline{\text { March 1 }}{ }^{\text {st }}$ & & 1936.7 & 7.02 & 8.9 & 1582.5 & 6.20 & 9.3 \\
\hline April 1 ${ }^{\text {st }}$ & & 1817.5 & 6.36 & 10.5 & 1498.0 & 5.52 & 10.9 \\
\hline May $1^{\text {st }}$ & & 1708.3 & 5.37 & 12.7 & 1424.2 & 4.80 & 13.2 \\
\hline L.S.D at 0.05 & & 53.4 & 0.39 & 0.4 & 21.0 & 0.22 & 0.5 \\
\hline \multirow{4}{*}{ cultivar } & Paulista & 1963.3 & 7.45 & 10.5 & 1602.2 & 6.70 & 10.9 \\
\hline & Samantha & 1728.9 & 5.57 & 10.0 & 1413.3 & 4.65 & 10.3 \\
\hline & Narina & 1776.7 & 6.28 & 11.3 & 1483.3 & 5.89 & 11.7 \\
\hline & Bronco & 1814.4 & 5.69 & 10.9 & 1507.8 & 4.79 & 11.4 \\
\hline L.S.D at 0.05 & & 44.3 & 0.4 & 0.3 & 18.8 & 0.31 & 0.2 \\
\hline \multirow{4}{*}{$\operatorname{March} 1^{\text {st }}$} & Paulista & 2050 & 8.26 & 8.8 & 1650 & 7.71 & 9.1 \\
\hline & Samantha & 1826 & 6.19 & 8.5 & 1500 & 5.16 & 8.5 \\
\hline & Narina & 1910 & 7.30 & 9.4 & 1570 & 6.65 & 9.9 \\
\hline & Bronco & 1960 & 6.33 & 9.1 & 1610 & 5.30 & 9.5 \\
\hline \multirow{4}{*}{ April $1^{\text {st }}$} & Paulista & 1950 & 7.57 & 10.2 & 1600 & 6.61 & 10.7 \\
\hline & Samantha & 1740 & 5.78 & 9.8 & 1400 & 4.68 & 10.3 \\
\hline & Narina & 1770 & 6.19 & 11.2 & 1490 & 5.97 & 11.4 \\
\hline & Bronco & 1810 & 5.92 & 10.7 & 1503 & 4.82 & 11.0 \\
\hline \multirow{4}{*}{ May $1^{\text {st }}$} & Paulista & 1890 & 6.54 & 12.5 & 1557 & 5.78 & 13.0 \\
\hline & Samantha & 1620 & 4.75 & 11.8 & 1340 & 4.12 & 12.1 \\
\hline & Narina & 1650 & 5.37 & 13.3 & 1390 & 5.04 & 13.9 \\
\hline & Bronco & 1673 & 4.81 & 13.1 & 1410 & 4.25 & 13.7 \\
\hline L.S.D at 0.05 & & 76.8 & 0.7 & 0.5 & 32.5 & 0.53 & 0.4 \\
\hline
\end{tabular}

\section{References}

Abdel Hakim, W.M., Y.M.M. Moustafa, and R.H.M. Gheeth, 2012. Foliar application of some chemical treatments and planting dates affecting snap bean (Phaseolus vulgaris L.) grown in Egypt. J Hort Sci and Ornamental plants, 4:307-317.

Abou El-Hassan, E.A., A.H.M. Shahien and M.S. Youssef, 1993. Effect of nitrogen and phosphors fertilizer on some cultivars of bean plants. 1-Morphological characters, yield and pod characteristics. Minia, First Conference on Horticultural Crop from 19-21 October.

Amanullah, J.I., T.F. Hayat, A.I. Khan and N. Khan, 2002. Effect of sowing dates on yield and yield components of mash bean varieties. Asian J . Plant Sci., 1: 622-624 
Amer, A.H., M. El-Desuki, O.M. Sawan, and A.M. Ibrahim, 2002 b. Potentiality of some snap bean (Phaseolus vulgaris L.) varities under different irrigation levels at Shark El-Owinat region Egypt. J. Appl. Sci., 17: 327-345.

Amer, A.H., O.M. Sawan, and S.R. Salman, 2002 a. Water requirements of snap bean (Phaseolus vulgaris $L$.) as affected by sowing date under newly reclaimed soil at shark El-Owinat region. J. of Agric Sci. Mansoura Univ., 27: 6097-6107.

Association of official agriculture chemists AOAC, 1990. Official Methods of Analysis- $15^{\text {th }}$ ed. Association of Official Analytical Chemists, Washington DC USA.

Axlesson L.C., B. Klockare, and A.S. Sandelius, 1981. The function of carotenoids during chloroplast development. [1] Protection of prolamellar body and enzymes for chlorophyll synthesis from photodestruction sensitized by early forms of chlorphyll. In Proc. $5^{\text {th }}$ Int. Cong. On photosynthesis Halkidik. Greece, 295-304.

Bekheta, M.A., and H.M.S. E-Bassiouny, 2005. Response of two wheat cultivars grown under salinity stress to putrescine treatment. J Agric Sci Mansoura Univ 30: 4505-4521.

Brown, I.D., and O. Lilleland, 1946. Rapid determination of potassium and sodium in plant material and soil extracts by flame photometery. Proc. Amer. Soc. Horti. Sci. 48: 314-346.

Chapman, H.O., and P.E. Pratt, 1978. Method of analysis of soils, plants and water. Univ of California Agric Sci Priced Publication, 4034: 50.

Cowling, S.A., and R.F. Sage, 1998. Interactive effects of low atmospheric $\mathrm{CO}_{2}$ and elevated temperature on growth photosynthesis and respiration in (Phaseolus vulgaris L.) Plant cell and Environmental, 21: 427-435.

Daningsih, E., D.L. Coffey, J. Loyan, C.A. Mullins, and R.A. Straw, 1994. Snap pod yield and pod quality as affected by planting date. Tannessee Farm and Home Sci. 170: 6-11

Dhanjal, R., O. Prakash and I.P.S. Ahlawat, 2001. Response of French bean (Phaseolus vulgaris L.) varieties to plant density and nitrogen application. Indian J. Agron., 46: 277-281.

Dubios, M., K.A. Gilles, J.K. Hamilton, P.A. Robers, and F. Smith, 1965. Colorimetric method for determination of sugars and related substances. Analyt., Chem., 38: 350.

El-Noemani, A.A., H.A. El-Zeiny, A.M. El-Gindy, E.A. El-Sahhar, and M.A. El-Shawadly, (2010) Performance of some bean (Phaseolus vulgaris L.) varieties under different irrigation systems and regimes. Australian Jour. of Basic and Applied Science, 4: 6185-6196.

El-Sayed, S.F., 1990. Comparative on some common bean cultivars. II. Chemical composition. J. Agr. Res. Tanta Univ., 16: 501-507.

El-Sefi, S.K., A. Elighawary, and M.M. Moursy, 1991. Effect of sowing date and number of plants per hill of snap bean for export. 1- on plant growth characters. Egypt. J. Appli. Sci., 6: 294-308.

El-Sefi, S.K., A. El-Mighawary, and M.M. Moursy, 1991. Effect of sowing date and number of plants per hill for snap bean for export 2-on yield and its components. Egypt. J. Appli. Sci., 6: 28-35.

Feleafel, M.N., and Sanaa M., El-Araby, 2001. Response of snap bean cultivars (Phaseolus vulgaris L.) to varing rates of nitrogen and phosphorus fertilization. J. Agric. Sci. Mansoura Univ., 26: 17351748.

Fyfe, P., R.J. Cogdell, C.N. Hunter, and M.R. Jones, 1995. Study of the carotenoid binding pocket of photosynthetic reaction center from the purple bacterium rohodobacter spharodes. In: photosynthesis from light to Biosphere P. Mathis (ed.). Vol. II: 47-50 in proceeding of $\mathrm{X}^{\text {th }}$ International Photosynthesis Congress, Montpellier France, 20-25 August.

Garg. N., 2002. Salinity stress-induced changes in key metabolism in the nodules of Glycine max L. (soybean) and Cicer arietinum L. (chick pea) and the maneuverability of their response through plant growth regulators. J. Plant Biol., 29-137-142.

Gomez, K.A., and A.A. Gomez, 1984. Statistical Procedures for Agricultural Research, $2^{\text {nd }}$ ed. Willey. Interscience New York.

HEIA, 2003. Horticultural Export Improvement Association. HEIA Newsletter. Issue 22, July/September 2003. Cairo, Egypt.

Hernadez, G.V., N. Toscano, L. Gomez, and M. Mullings, 1996. The effect of phosphorus concentration on assimilation by three genotypes of common bean (Phaseolus vulgaris L.). Agronomia mesoa mericena, 7: 80-85. 
Ibrahim, K.S., A.F.M. Shalaby, M.E. Zaki, F.A. Abou-Sedra, and M.S.A, Abd Allah, 2012. Alleviation of high temperature stress on snap bean (Phaseolus vulgaris L.) by benzyl adenine and putrescine. J. of App. Sci. Res., 8: 192-199.

Ismail, A.I., W.S. Ragheb, and S.M. Mahmoud, 1996. Effect of sowing date and plant spacing on seed yield and quality of climbing bean (Phaseolus vulgaris L.) cv. Serbo grown under plastic houses. Egypt J. Hort., 22: 31-40.

Karas, A.N., S.M. Singer, O.M. Sawan, and A.F. Abou Hadid, 1999. Water consumption of bean plants (Phaseolus vulgaris L.) as affected by sowing dates. Egypt J. Hort., 26: 19-34.

Khalil, S.I., H.M.S. El-Bassiouny, R.A. Hassanein, H.A.M. Mostafa, S.A. El-Khawas, and A.A. AbdEl Monem, 2009. Antioxidant defense in heat shocked wheat plant previously treated with arginine or putrescine. Aust. J. Basic App. Sci., 3: 1517-1526.

Mamata, J., N.G.L. Patange, and J.D. Shubhangi, 2011. Effect of sowing dates on growth and yield of frensh bean (Phaseolus vulgaris L.) varieties during Kharif season. Advances Res. J of Crop Improvement, 2: 158-160.

Maniruzzaman, M., S.M.L. Rahman, M.G. Kibria, M.A. Rahman, and M.O. Kaiser, 2007. Performances of vegetable French bean as influenced by varieties and sowing dates in Rabi season for getting higher pod yield. Int. J. Sustain Crop Prod. 2: 69-73.

Metzner, H., H. Ran, H. Senger, 1965. Unteresuchugen zur sychronisier barkit ein zeiner pigment Mangol Mutanten, Von. Chlorila. Plant, 65: 186.

Mohamed, F.M., 1997. Screening f some common bean (Phaseolus vulgaris L.) cutivars or production in southern Egypt and pan coefficient analysis for green pod yield. Assiut. J. Agric. Sci., 28: 91106.

Mohamed, M.F., 1997. Screening of some common bean (Phaseolus vulagris L.) cultivars for production in southern Egypt and path coefficient analysis for green pod yield. Assiut J. of Agric. Sci., 18: 91-106.

Papadakis, A.K., and A.K. Roubelakis-Angelakis, 2005. Polyamines inhibit NADH oxidase-mediated superoxide generation and putrescine prevents programmed cell death induced by polyamine oxidase-generated hydrogen peroxide. Planta., 220: 826-837.

Perez-Barbeito, M., A.M. Conzalez, A.P. Rodino, A.M. De Ron, and M. Santalla, 2008. Effects of planting season and plant cultivar on growth, development and pod production in snap bean (Phaseolus vulguris L.) Aust. J. of Agric. Res. 59: 1121-1129.

Pirie, E.G., 1955. Proteins in: Modern Methods of Plant Analysis. Edited by Peach K. and M.V Trancey, IV: 23-68 Springer Verlag Berlin.

Reichel, S., 1992. Late French bean with different cultivars Gartenbau Magazin, 1: 91-93.

Kakon, S.S., M.A.K. Main, R.R. Saha, S.S. Nasreen, Q. Naher, and M.A. Hossaien, 2018. Phenology, growth and pod yield of French bean (Phaseolus vulgaris L.) as influenced by temperature variations under different sowing dates. Bangladesh Agron. J., 21(2): 25-32

Sabal, R.N., S.B. Want, and T.D. Dalvi, 2010. Evaluation of sowing time for raby French bean and validation by DSSA.

Siprin, A.S., 1958. Spectrophotometric determination of total nucleic acids content. Biochem., 23: 617622.

Youssef, A.M., 2000. A comparative study on some new snap bean cultivars grown under protected cultivation. Egypt J. Hort., 27: 337-348.

Zeyada, A., and A.M. Hussien, 2014. Effect of sowing date and plant population on snap bean (Phaseolus vulgaris L.). Growth and Pod yield in Khartoum state. Universal J. of Agric. Res., 2: 115-118. 